\title{
Barely legal: Racism and migrant farm labour in the context of Canadian multiculturalism
}

Author: J. Adam Perry

Citation: J. Adam Perry (2012): Barely legal: racism and migrant farm labour in the context of Canadian multiculturalism, Citizenship Studies, 16:2, 189-201

\begin{abstract}
This article investigates how colonial attitudes towards race operate alongside official multiculturalism in Canada to justify the legally exceptional exclusion of migrant farm workers from Canada's socio-political framework. The Canadian Seasonal Agricultural Workers Program (CSAWP) is presented in this article as a relic of Canada's racist and colonial past, one that continues uninterrupted in the present age of statist multiculturalism. The legal continuation and growth in the use of non-citizens to conduct labour distasteful to Canadian nationals has provided an effective means for the Canadian state to regulate the ongoing flow of non-preferred races on the margins while promoting a pluralist and ethnically diverse political image at home and abroad. In the face of a labour shortage constructed as a political crisis of considerable urgency, the Canadian state has continued to admit non-immigrants into the country to perform labour deemed unattractive yet necessary for the well-being of Canadian citizens while simultaneously suspending the citizenship and individual rights of those same individual migrant workers. By legislating the restriction of rights and freedoms to a permanently revolving door of temporary non-citizens through the mechanism of a guest worker program the Canadian state is participating in the bio-political regulation of foreign nationals.
\end{abstract}




\section{Introduction}

This article investigates how colonial attitudes towards race operate alongside the discourses of diversity and multiculturalism to justify the overt and legally exceptional exclusion of migrant farm workers from Canada's social and political framework. The Canadian Seasonal Agricultural Workers Program (CSAWP) is presented in this article as a relic of Canada's racist and colonial past, one that continues uninterrupted in the present age of statist multiculturalism, first owing to the state-sanctioned amputation of any collective memory related to Canada's history of inequitable race relations and second by virtue of the CSAWP's articulation as an 'exception' to standard citizen-track immigration practices. The legal continuation and growth in the use of non-citizens to conduct labour distasteful to Canadian nationals has provided an effective means for the Canadian state to regulate the ongoing flow of non-preferred races on the margins while promoting a pluralist and ethnically diverse political image at home and abroad. In order to maintain the health of the Canadian populace in the face of a labour shortage in the Canadian agricultural sector constructed as a political crisis of considerable urgency, the Canadian state has continued to admit non-immigrants into the country to perform labour deemed unattractive yet necessary for the well-being of Canadian citizens while simultaneously suspending the citizenship and individual rights of those same individual migrant workers. By legislating the restriction of rights and freedoms to a permanently revolving door of temporary non-citizens through the mechanism of a guest worker program the Canadian state, both in spite of and due to the promotion of multiculturalism as official policy, is participating in the bio-political regulation of foreign nationals. 


\section{The Canadian Seasonal Agricultural Workers Program (CSAWP)}

As a response to perceived labour shortages in its agricultural sector, Canada has been importing temporary foreign agricultural workers since 1966 when 264 Jamaican workers came to the Canadian province of Ontario to harvest tobacco. In the past 44 years the Canadian Seasonal Agricultural Workers Program (CSAWP) has grown significantly, and in 2005 there were more than 20,000 migrant farm workers from Mexico and the Caribbean employed temporarily in Canada - 16,000 of these in Ontario (United Food and Commercial Workers, 2009). It has been argued that these numbers are evidence that the CSAWP has become a structural necessity to Canada's agricultural sector (Basok 2002). However, while this program fulfils the employment needs of Canada's farmers, it has had serious effects on the workers and communities involved (Preibisch 2004, 2005, 2007; United Food and Commercial Workers 2009).

Through the CSAWP a category of worker has developed to perform labour unattractive to Canadians who is non-citizen, foreign and temporary with no legal entitlement to benefits permitted to Canadian citizens (Barndt 2002; Basok 2002; Bolaria and Li 1988; Sharma 2006). Paternalistic and exploitative social relations have developed as workers' public and private lives are closely regulated by their employers, who provide not only work, but also transportation and housing (Barndt 2002; Paz 2008). These unequal social relations are framed by the structural inequalities involved in the construction of what it means to be a migrant labourer in Canada as per the regulations of the CSAWP (Preibisch 2004, 2005, 2007). The language divide between workers and local Canadians exacerbates these inequalities, as workers are largely excluded from the social fabric of the regions where they reside (Basok 2002).

The CSAWP is Canada's oldest temporary foreign labour program, but Canada's use of temporary foreign labour does not end with farm workers. Given the 
success of the CSAWP to address the labour needs of farmers, the Canadian government has been expanding the use of temporary foreign labour in both low and high-skilled labour sectors. The number of temporary foreign workers in Canada is growing; in the past 3 years Canada has admitted more temporary than permanent residents (Office of the Auditor General of Canada 2009). The Fall 2009 report from the Auditor General of Canada as well as other sources (Alboim and Maytree Foundation 2009; Walia 2009) report that the influx of temporary workers is displacing citizen-track immigration. In search of an ever more flexible workforce, in 2002 the federal government created a low-skilled temporary foreign worker pilot project, now a full-fledged program, to fill employment needs in construction and service-industry positions. Often, workers who participate in these programs would not meet the selection criteria put in place for economic immigrants, such as language proficiency, level of education, and occupational classification. In December 2007 there were 201,057 temporary foreign workers in Canada, over half (57\%) of whom had entered the country for the first time that year (Tilson 2009, p. 1). These numbers suggest that the Canadian government favours the flexibility that temporary programs permit over the long-term costs and responsibilities that accompany permanent immigration from economic immigrants and refugees.

The increased use of temporary migrant labour is a signal that the Canadian government is shifting its focus away from citizen-track immigration by promoting the use of programs that favour the perpetual circulation of non-Canadians to fill a vast range of labour shortages while simultaneously maintaining a backlog of nearly $1,000,000$ unprocessed applications for permanent residency as reported by Citizenship and Immigration Canada in 2008 (Tilson 2009). Encouraging temporary foreign employment over citizenship-track immigration can be characterized as what 
Goldberg (2009) has coined the transformation of the state from caretaker of the population's welfare to that of a traffic cop which "polices flows human, capital, and commodity, regulating the political, cultural, and economic" (p. 39). My analysis will investigate how colonial attitudes towards race (Satzewich 1991) operate in tandem with the discourses of diversity and multiculturalism (Bannerji 2000; Thobani 2007) to justify the overt and legally exceptional exclusion of migrant farm workers from Canada's social and political framework.

\section{Racism and migrant farm labour in an age of multiculturalism}

Racism against Mexican and Caribbean workers who participate in the CSAWP is not a matter relegated to the privacy of worker/employer relations; rather epistemic and material violence conducted against racialized bodies is necessarily embedded in the structural organization of the CSAWP. The racial configuration of the CSAWP is structured in such a way as to perform a social function: while Canadian farmers and the wider Canadian population reap the benefits of the program by gaining profits, an unfettered labour supply, and an endless supply of agricultural products, Mexican and Caribbean governments, whereas they may generate revenue through remittances, pay the price in terms of the loss of social capital and human resources and the high costs of long-term health care of returning migrant workers, as illustrated by Sassen-Koob (1978, p. 519). This situation results in individual workers being thrown into a situation where their rights are systemically restricted and where they are open to an elevated risk of abuse and harassment that would be deemed unacceptable in most other Canadian workplaces or social settings (Office of the Auditor General of Canada 2009). Individual migrant workers pay the price of the program in terms of familial estrangement, exposure to dangerous pesticides, and in many cases tremendous social isolation (Basok 2002). 
One of the first academic works that dealt with the phenomenon of temporary foreign labour on Canadian farms dealt directly with race. Satzewich (1991) presents a history of foreign farm labour that incorporates an analysis of the beginning of the CSAWP. He examines the role that racism played in the structural establishment of Canada's first temporary foreign labour program. He describes a process whereby Caribbean workers were defined as a 'race' apart from the dominant 'white' Canadian population whose presence in the country would pose serious problems. This attitude was clearly articulated in 1947 by the then Director of the Immigration Branch:

The admission to Canada of natives of the West Indies has always been a problem with this Service and we are continually being asked to make a provision for the admissions of these people. They are, of course not assimilable and generally speaking, the climatic conditions of Canada are not favourable for them (as cited in Satzewich 1991, p. 172).

This "ideology of racism," Satzewich writes, "structured the decision to exclude these people from entry to the country and subsequently to allocate them to positions as unfree migrant labour" (p. 171). From the very beginning, migrant farm workers have been, in the words of David Goldberg, "demarcated to strangers and exploitable labour" (Goldberg 2009, p. 42). The offshore program provided a solution to the problem of labour shortages on farms by creating a program organized along clear racial hierarchies of black/guest (i.e. worker) and white/host (i.e. owner). The program later incorporated Mexican workers whose numbers have been increasing and now surpass the numbers of workers from the Caribbean (Binford 2002). Binford (2002) argues that the decision to include Mexican workers in the mix was also racially motivated, as farmers were complaining that their Caribbean workers were demanding time off, worked slowly, and refused to work long hours. Binford associates Caribbean workers' willingness and capacity to resist exploitation to their ability to speak English and to their history of pre- and post-slavery relations with White Europeans, "which may translate into different expectations regarding 
treatment and different styles of handling labor demands and authority relations" (Binford 2002, p. 10). Mexican workers, who speak Spanish (or in many cases one of many languages indigenous to Mexico), and do not have the same history with strict racial categories, were seen by farmers as more docile and hence easier to exploit (Binford 2002, p. 10).

Satzewich's (1991) historical analysis of migrant farm labour reveals that an essentializing racist discourse was at work during the creation of and justification for Canada's first temporary foreign worker program. Migrant workers were characterized by immigration officers as inassimilable, backwards, and a danger to Canadian society. Officials in 1963, for example, provided descriptions of the male 'Negro' as “childlike, indolent, lazy and stupid” (Satzewich 1991, p. 136). Satzewich characterizes these views as similar to eighteenth and nineteenth century racial stereotypes used to justify slavery and colonialism as described by Said in Orientalism (Said 1979). The construction of the collective Western bourgeois subject, according to Said, is constituted through the encounter with an 'other' that is seen as radically different, primitive and backwards, a deficient 'other' from which the subject is able to distinguish itself and through which it takes its form. The creation of just such an 'other' through the incorporation of the CSAWP into the organization of labour migration on Canadian farms serves to constitutes a Canadian subject that can be characterized as free, autonomous and sovereign in contrast to his or her unfree and dependent labourers. Disturbingly, the incorporation of 'unfree' migrant labour on Canadian farms also serves to constitute the Canadian subject as 'owner' through growers' experiences of having been bestowed the power of absolute discipline over the bodies of their racialized, non-Canadian, unfree and provisional employees, leading one migrant worker from Mexico to observe that "slavery has not 
yet disappeared" (as cited in El Contrato 2006). This exalted subjectivity is materialized through the CSAWP, which offers Canadian growers who participate in the program an inordinate amount of power that includes the power to execute racial and gender discrimination in the workplace, the ability to repatriate workers on a whim, and complete control over the basic housing and physical mobility of their workers (Basok 2002; United Food and Commercial Workers 2009).

Not incidentally, the creation of Canada's first experiment with temporary migrant farm workers in 1966 and subsequent adoption of non-immigrant work authorization regulations in 1973 (Bolaria and Li 1988, p. 196; Sharma 2006) coincide with both Canada's adoption of multiculturalism as official state policy in the 1980s and the state's restructuring of immigration policies in the 1960s and 1970s, whereby the Canadian state eliminated overtly race-based immigration policies in favour of immigration regulations based on a point system that emphasized labour market needs (Thobani 2007). As has been established by Satzewich, it has been pointed out how race is used to justify the exploitation of migrant farm workers in Canada, usually through highlighting the racist behaviour of individual employers. For example, Bolaria and Li (1988) publish quotes from employers who justify the unequal treatment of their offshore Mexican workers through references to the racial inferiority of Mexicans (p. 200). Similar quotes are showcased in the recent documentary film El Contrato (2006), which follows the lives of two Mexican migrant farm workers during their stay in the town of Leamington, Ontario. Several growers are interviewed in the film, and one in particular, in her attempt to describe Canadian hospitality toward foreign workers reveals that it is no big deal for locals when some of the workers go into town on weekends to get inebriated, as "the police just call their owners and they come pick them up" (as cited in El Contrato 2006). 
Little has been written, however, on how race, employed as the justification of an exploitative migrant worker program, is able to operate within the Canadian political context of a liberal democratic society where overt racism has been eliminated from the domain of immigration policy and has been replaced by the discourse of diversity and institutionalized multiculturalism.

There is a significant literature that examines how multiculturalism is a mechanism whereby former colonial powers who have reinvented themselves into liberal democratic states are able to manage the difference of their internal 'Others' while simultaneously claiming the cultural superiority of the racial majority (Ahmed 2000; Hage 2000; Thobani 2007). In Canada, Bannerji (2000) has examined the role that the discourse of diversity and officially sanctioned state multiculturalism play in managing and administering difference in Canadian society. She argues that multiculturalism replaces the emphasis on cultural diversity, thus facilitating the erasure of power relations and historical understandings of race and racism. By adopting multiculturalism as a state-sanctioned, state organized ideological matter Canada comes to identify itself as a multi-ethnic, multinational state where power relations rooted in its history of racialized class formation and colonization are hidden and where the discourse of diversity "emerges as a value-free, power neutral indicator of difference and multiplicity" (Bannerji 2000, p. 36). Far from being value neutral, however, the emphasis on plurality and cultural essence "obscures any understanding of difference as a construction of power" (p. 36). The discourse of diversity, made material and extended in the form of the discourse of official multiculturalism is a complex ideological tool for deflecting racism through which difference becomes socially abstracted from power and "[c]ultural sensitivity towards and tolerance of 
others... are two behavioural imperatives... both at the level of state and society" (p. 40).

Building on Bannerji's analysis, Thobani (2007) argues that the liberalization of immigration policies and the adoption of state multiculturalism were unavoidable political decisions due to labour demands at home and the fact that immigration policies based overtly on race could no longer be defended in the age of civil rights and decolonization (p. 146). She argues that these national policy decisions were ultimately pragmatic and as such were more motivated by the pressure of global public relations and not by popular demand that Canada disavow racism. The liberalization of immigration policy in Canada signaled the birth of global capitalism (Sharma 2006) and an overt switch away from overtly colonial attitudes (Thobani 2007). Whereas official multiculturalism facilitated the material inclusion of immigrants into the Canadian population, it also simultaneously facilitated their exclusion from the nation through their reification as cultural outsiders (Bannerji 2000). By deflecting overt racism, however, Thobani argues that statist multiculturalism in Canada has enabled the preservation of white domination and has been critical in the reconstitution of the Canadian subject as a white, culturally tolerant cosmopolitan national. In the words of Thobani (2007), official multiculturalism has "facilitated a more fashionable and politically acceptable form of white supremacy which has had greater currency within a neocolonial, neoliberal global order" (p. 148). Thus Canada's embrace of official multiculturalism facilitated the renewed empowerment of white identity at a political moment when global white supremacy was undergoing a crisis of legitimacy. Canadians were invited to eschew their racist past and reinvent themselves as tolerant and pluralist national subjects. 
Canada's policy of official multiculturalism, as a state-level discursive device which promotes ethnic plurality and cultural tolerance while simultaneously concealing the state's continued and historical involvement in the oppression of racialized bodies, facilitates the process of redirecting the accountability of institutionalized racism from the state to individuals (Goldberg 2009, p. 362). Thus, the cruel and dehumanizing treatment of racialized migrant workers through the CSAWP is maintained by veiling the violence embedded in the program through the transfer of structurally sanctioned racism to the realm of civil society and individual citizens. When asked about the risk of abuse and exploitation to migrant workers, officials from Citizenship and Immigration Canada (CIC) and Human Resources and Service Canada (HRSDC) explained to the authors of the Fall 2009 Auditor General's report (Office of the Auditor General of Canada 2009), that they had no authority to "conduct compliance reviews of employers who have not consented" to a review (p. 34). The unregulated exploitation and abuse of migrant workers can therefore take place uninterrupted. The CSAWP is self-regulated and administered by Foreign Agricultural Resource Management Services (F.A.R.M.S), a private-sector non-profit organization governed by a board of directors chosen by farmers (FARMS 2010). Responsibility for the administration of the program and ultimately the well-being of the workers is therefore transferred from the public to the private arena. The racism that Satzewich (1991) and others (Bolaria and Li 1988) argue is embedded in the very notion of a guest worker program is thus rendered civil, and the epistemic violence associated with essentializing racial prejudices and the material violence connected to the everyday exploitation of migrant labour can thus remain hidden: any occurrences of abuse are relegated to the domain of individual employer/employee relations or to the actions of a few bigoted townsfolk. 
Goldberg (2009) describes this phenomenon as the positioning of socially sanctioned violence out of sight. He says: “... civil society and the civilities on which it is built displace race and the warrant of its exclusions from state practice to privatized and individualized expression" (p. 52). It has been shown through interviews with migrant workers, farmers, and government officials, that the overall success or failure of the CSAWP hinges on the relationships that workers develop with their employers (Preibisch 2007, pp. 14-15). The program itself, Preibisch (2007) reveals, is seen as relatively benign, and most farmers are perceived as 'good'. Any instances of racism or abuse against migrant farm workers are explained away as anomalies: the unfortunate transgressions of a few bad employers. Preibisch (2007) discusses how racism is both materialized and made to disappear in the relationships that develop in rural Ontario between workers, their employers, and local community members. She discusses how local Canadians go out of their way to avoid social contact with workers and even how some farmers have been shown to conceal workers' housing behind packing sheds so as not to bother their neighbours. One resident commented on how farmers are "very careful to keep the housing for the offshores out of sight because the neighbours will complain" (as cited in Preibisch 2007, pp. 21-22).

The deflection of racism away from the domain of state policies, facilitated through the discursive mechanisms of 'diversity' and 'multiculturalism', encourages hidden and privatized methods of organizing race in Canada. Goldberg (2009) describes such a process as racism becoming conceptually stigmatized "so that obviously the bigoted - extreme individuals - get to qualify... Racism is reduced... to invoking race, not to its debilitating structural effects or to the legacy of its ongoing unfair impacts" (p. 360). However, far from racism against migrant farm workers 
being an isolated problem associated with the odd farmer, colonial attitudes towards race are embedded in the very notion of Canada's agricultural guest worker program. The CSAWP is an ongoing relic from a haunting past; the dubious legacy of premulticultural, overtly racist immigration practices whose roots can be found in the practice of slavery in Canada (Bolaria and Li 1988, pp. 185-205) as well as in the exploitation of working-class Chinese immigrants who were denied the right to immigrate with their families (Adilman 1984, p. 56) in order to mitigate the "potential to overwhelm the whiteness of the nation..." (Thobani 2007, p. 130). However, despite this dubious history, the CSAWP continues to operate unimpeded in an age of statist multiculturalism. The discursive erasure of any memory of racism and power relations from Canadian history enables the state to produce a type of anomalous zone in the vein of Agamben's (2005) notion of a state of exception where the rights and freedoms of migrant workers are restricted and justified by not only 'severe labour shortages' (Basok 2002; Tilson 2009, p. 2) but also by widespread representations of racialized migrants from Mexico and the Caribbean as both socially objectionable and yet worthy of Canadian foreign economic assistance (Bauder 2008).

\section{A crime of compassion?: The legal exploitation of non-preferred racialized migrants}

The adoption of official multiculturalism empowered white identity in Canada through allowing Canadians "to resolve the crisis of whiteness through its reorganization as tolerant, pluralist, and racially innocent, uncontaminated by its previous racist history" (Thobani 2007, p. 154). Rather than producing a more equitable society the erasure of this history from collective memory has facilitated the continued exclusion of racialized others, particularly with regards to ongoing overtly racist practices on Canada's economic margins. As the new immigration policies of the 1960s and 1970s rejected overtly racist policies, the Canadian government was 
compelled to provide a legal exception for the inclusion of foreign non-preferred races to continue to perform non-preferred jobs on a permanently temporary basis. Sharma (2006) describes how this situation led to the creation the Non-Immigrant Employment Authorization Program in 1973 and of a new class of worker who was transmigrant, temporary, and 'non-Canadian'. She reveals that the Canadian government, bound to grant, in the words of then Prime Minister Pierre Trudeau, "freedom of choice for citizens [italics added] to work where they want" (as cited in Sharma 2006, p. 98), developed a category of worker who was a non-citizen: foreign and temporary, with no legal entitlement to benefits permitted to Canadian citizens. Canadian farmers who had difficulty finding locals to perform agricultural work were granted the capacity to order as many Mexican or Caribbean male or female workers as they needed or desired. The legal continuation and growth in the use of noncitizens to conduct labour distasteful to Canadian nationals provided an effective means for the Canadian state to regulate the ongoing flow of non-preferred races on the margins while promoting a pluralist and ethnically diverse political image at home and abroad.

Ahmed (2000) argues that the discourse of statist multiculturalism can produce a contradictory process of simultaneous inclusion and exclusion of a nation's internal 'Others'. According to Ahmed's analysis, a multicultural society like Canada may promote a kind of 'stranger fetishism' whereby there comes to be a differentiation between "those strangers whose appearance of difference can be claimed by the nation, and those stranger strangers who may yet be expelled, whose difference may be dangerous to the well-being of even the most heterogenous of nations" (p. 97). In the case of the CSAWP, this 'stranger fetishism' is articulated in the form of what Agamben (2005) describes as a 'state of exception', a state of legalized lawlessness 
that is a response to a situation of the political crisis of a shortage of low-skilled labour on farms and justifies that which "appears as the legal form of what cannot have legal form" (p. 1).

The Canadian state, in the form of the CSAWP, has created a legislated yet ambiguous zone where migrant farm workers are legally disenfranchised and legally denied citizenship rights and as such are exposed to an elevated risk of abuse and exploitation (Office of the Auditor General of Canada 2009). For example, migrant workers who participate in the CSAWP are indentured to their employers for the duration of their contracts. Workers cannot seek out their own housing as they are obliged to accept workplace housing from their employers. This policy serves as an overt exclusion of migrant farm workers from the framework of Canadian society, as workers often end up living in geographically isolated bunkhouses which are often cramped, substandard, overcrowded, and which pose potentially serious health and safety risks to the workers (Preibisch 2007, p. 15). As non-Canadians, migrant workers who participate in the CSAWP do not have the ability to quit and find work elsewhere, as they do not have the right to work within free employment relationships characteristic of capitalist production. Unless a transfer is arranged with the employer's permission, workers are required to remain with their governmentapproved employers for the entirety of their contract, which is usually for about six to eight months.

Many workers inexorably find themselves in thorny employment situations while in Canada: however, CSAWP repatriation provisions are such that any worker who raises concerns to their employer risks being sent home. Under the CSAWP repatriation rules, "workers can [be] and are sent home by their employer, often with just a day or two's notice, for any reason", including when workers become sick or 
injured (United Food and Commercial Workers 2007, p. 9). No provision is made for appeal. In fact, whereas employers are provided with mechanisms such as repatriation to discipline workers, no such mechanisms are granted to the workers who wish to make complaints about exploitative or abusive conditions (Binford 2002). Thus, the 20,000 individual migrant workers who make up the CSAWP are bound contractually to one employer in a structurally precarious, often times dangerous work situation in a foreign country far away from their families where, as non-citizens, they have few rights. By legislating the restriction of rights and freedoms to a permanently revolving door of temporary non-citizens through the mechanism of a guest worker program the Canadian state, both in spite of and due to the promotion of multiculturalism as official policy, is participating in the bio-political regulation of foreign nationals. Foucault (2003) describes biopower as the mechanism which regulates global relationships between populations and racism as the method through which this process is able to take place. As such, it is no accident that the CSAWP has been organized according to racial hierarchies. According to Foucault, as the primary function of the state towards its population is to preserve life, then it must be possible for the state to be granted the power to conduct violence against those that could put the health of the collective body at risk. He explains: "the death of the other, the death of the bad race, of the inferior race (or the degenerate, or the abnormal) is something that will make life in general healthier: healthier and purer" (p. 255). That Canada's racialized 'guests' are responsible for growing and cultivating the very food which nourishes the Canadian 'host' population further highlights the bio-political significance of the CSAWP. Thus, in order to maintain the health of the Canadian populace in the face of a shortage of "cheapened and politically subjugated labour power" (Sharma 2006, p. 108) constructed as a political crisis of considerable urgency 
(Solberg 2007, p. 1; Tilson 2009, p. 2), the Canadian state has continued to admit nonimmigrants into the country to perform labour deemed unattractive yet necessary for the well-being of Canadian citizens while simultaneously suspending the citizenship and individual rights of those same individual migrant workers. As such, a biopolitical analysis of the CSAWP, which is deemed a necessary response to collective phenomena which have their affect at the political and economic level and which are significant on a mass scale, reveals the programs purpose as to

establish an equilibrium, maintain an average, establish a sort of homeostasis, and compensate for variations within this general population... In a word, security mechanisms have to be installed around the random element inherent in a population of living beings so as to optimize a state of life (Foucault 2003, p. 246).

The additional perception of the CSAWP as a means for providing economic assistance to less fortunate third-world others (Bauder 2008) serves to constitute the Canadian national as 'exalted subject' (Thobani 2007) while reproducing the biopolitical bond between compassionate Canadian hosts and their ill-fated foreign farm worker guests. This 'moral economy of care' finds resonance in the expression of Canada as a caring and tolerant nation while deflecting attention away from the history of overt racism in which the guest worker program is rooted.

The complexity of how the CSAWP is justified within the context of the discourse of Canadian multiculturalism is illustrated in Bauder's (2008) examination of representations of migrant agricultural workers in the Ontario daily newsprint media between 1997 and 2002. Bauder's research attempts to reveal the ideological underpinnings for the ways in which offshore agricultural labour is represented in the media and how media representations work to legitimate offshore labour exploitation. Bauder finds that the Ontario daily press not only represents popular views of migrant workers, but that it also plays an active role in legitimating the offshore program. Bauder presents the key elements of the CSAWP as serfdom, as a new kind of racism 
and arguments in favour of the program as a new kind of foreign aid. His study reveals that overall, the media portray migrant farm workers within these three seemingly contradictory, yet complimentary narratives: first as valuable economic resources, second as social problems in the rural communities where they live, and third their employment is depicted as a way of providing financial aid to impoverished families in the global south.

By examining a wide range of media over a period of five years, Bauder articulates a complex narrative in which foreign agricultural workers are seen as necessary for the farm economy to prosper while simultaneously not suited to permanent inclusion to Canadian society due to their inherent potential for criminal or dangerous behaviour, but rather maintaining they must regularly return to their countries of origin in order to deliver much needed Canadian aid to their poor families who have been left behind. Bauder's research demonstrates how the complexities of race and nationalism operate to justify the CSAWP as an exception to citizen-track immigration. Evoking the racist statements from immigration officials involved in the formation of the CSAWP (Satzewich 1991), migrant workers are represented in contemporary Canadian media as strangers who remain too strange and inassimilable to be allowed either citizenship or individual rights such as labour mobility. That migrant workers exist in an anomalous zone located outside of citizen-track immigration serves to bolster their already inherent strangeness. Borrowing again from Foucault (2003) and from Satzewich's (1991) historical analysis, race is the currency through which these narratives take shape. By simultaneously portraying migrant workers as dangerous others, the Canadian national subject is constituted as morally superior. The further narrative of compassion for poor third-world others serves to reify Canadians as caring and compassionate, and thus provides the moral 
authority to grant exceptions on the basis of compassionate grounds, further constituting the Canadian subject as generous host.

\section{Summary}

The CSAWP is presented in this article as a bio-political mechanism that admits non-citizens into the country to perform labour deemed necessary for the wellbeing of Canadian citizens while simultaneously restricting the rights and freedoms of those same individual migrants. The CSAWP is structured in such a way as to exclude racialized working class others from citizen-track entry into the country while demarcating them to a non-immigrant status as temporary, foreign and unfree labourers. The CSAWP is presented in this article as a relic of Canada's racist and colonial past, one that continues unimpeded in the present age of statist multiculturalism, first owing to official multiculturalism's role in the state-sanctioned erasure of any collective memory related to Canada's history of inequitable race relations and second by virtue of the CSAWP's articulation as an 'exception' to standard immigration practices based on cultural tolerance.

By constructing the perception of a quantitative labour shortage crisis the Canadian state has offered a concession to the agricultural economic sector in the way of an ambiguous legal entity through which foreign agricultural workers are legally disenfranchised and legally denied citizenship rights. As the workers who participate in the CSAWP would generally not meet the selection criteria put in place for economic immigrants, the Canadian state was induced to create a legalized exception to liberalized citizen-track immigration policies that replaced overtly racist immigration practices in Canada's immigration reform of the 1960s and 1970s. The present-day CSAWP operates as an exception to citizen-track immigration policies and rather has its roots in notoriously unexceptional and historical practices of racial 
subjugation such as slavery in the eighteenth century (Bolaria and Li 1988, p. 188)

and the restriction of the rights and freedoms of Chinese immigrants in the late nineteenth and early twentieth centuries (Adilman 1984). These overtly racist practices have persisted unfettered with the creation of the CSAWP thus normalizing the concepts of indentured labour and unfree servitude as ideas that are sutured to the very concept of what it means to be a migrant worker in Canada.

\section{References}

Adilman, T., 1984. A preliminary sketch of Chinese women and work in British Columbia 1958-1950. In: B. K. Latham and R. J. Pazdro, eds. Not just pin money: selected essays on the history of women's work in British Columbia. Victoria, B.C.: Camosun College, 53-78.

Agamben, G., 2005. State of exception (K. Attell, Trans.). Chicago: Chicago University Press.

Ahmed, S., 2000. Strange encounters: embodied others in post-coloniality. London: Routledge.

Alboim, N., and Maytree Foundation., 2009. Adjusting the balance: fixing Canada's economic immigration policies. Toronto: Maytree Foundation.

Bannerji, H., 2000. The dark side of the nation: essays on multiculturalism, nationalism and gender. Toronto: Canadian Scholars' Press Inc.

Barndt, D., 2002. Tangled routes: women, work, and globalization on the tomato trail. Aurora, Ontario: Garamond Press.

Basok, T., 2002. Tortillas and tomatoes: transmigrant Mexican harvesters in Canada. Montreal and Kingston: McGill-Queen's University Press.

Bauder, H., 2008. Foreign farm workers in Ontario (Canada): exclusionary discourse in the newsprint media. Journal of Peasant Studies, 35(1), 100-118.

Binford, L., 2002. Social and economic contradictions of rural migrant contract labor between Tlaxcala, Mexico and Canada. Culture and Agriculture, 24(2), 1-19.

Bolaria, B. S., and Li, P. S., 1988. Racial oppression in Canada (Second ed.). Toronto: Garamond Press.

El Contrato, 2006. Film. Directed by Min Sook Lee. Canada: National Film Board of Canada. 
FARMS, 2010. F.A.R.M.S. foreign agricultural resource management services [online]. Available from: http://www.farmsontario.ca/index.htm.

Foucault, M., 2003. "Society must be defended": lectures at the college de France 1975-1976 (D. Macey, Trans.). New York: Picador.

Goldberg, D. T., 2009. The threat of race: reflections on racial neoliberalism. Malden, MA: Wiley-Blackwell.

Hage, G., 2000. White Nation: fantasies of white supremacy in a multicultural society. New York: Routledge.

Office of the Auditor General of Canada., 2009. Chapter 2: selecting foreign workers under the immigration program. Ottawa: Office of the Auditor General of Canada.

Paz, A., 2008. Harvest of injustice: the oppression of migrant workers on Canadian farms. Socialist Voice [online]. Available from: http://www.socialistvoice.ca/?=301 [Accessed June 22 2008].

Preibisch, K., 2004. Social relations practices between seasonal agricultural workers, their employers, and the residents of rural Ontario. Ottawa: The North South Institute.

Preibisch, K., 2005. Gender transformation odysseys: tracing the experiences of transnational migrant women in rural Canada. Canadian Woman Studies, 24(4), 9197.

Preibisch, K., 2007. Patterns of social exclusion and inclusion of migrant workers in rural Canada. Ottawa: North-South Institute.

Said, E. W., 1979. Orientalism. New York: Vantage Books.

Sassen-Koob, S., 1978. The international circulation of resources and development: the case of migrant labour. Development and Change, 9, 509-545.

Satzewich, V., 1991. Racism and the incorporation of foreign labour: farm labour migration to Canada since 1945. New York: Routledge.

Sharma, N., 2006. Home economics: Nationalism and the making of 'migrant workers' in Canada. Toronto: University of Toronto Press.

Solberg, M., 2007. Building Canada's knowledge advantage: creating the best educated, most skilled and most flexible workforce in the world. Speech presented at the Public Policy Forum Conference on "Improving Canada's Business Environment and Competitiveness", 23 January, Ottawa.

Thobani, S., 2007. Exalted subjects: studies in the making of race and nation in Canada. Toronto: University of Toronto Press. 
Tilson, D., 2009. Temporary foreign workers and non-status workers: seport of standing committee on citizenship and immigration. Ottawa: House of Commons Canada.

United Food and Commercial Workers., 2007. The status of migrant farm workers in Canada 2006-2007. Rexdale, Ontario: United Food and Commercial Workers.

United Food and Commercial Workers., 2009. The status of migrant farm workers in Canada 2008-2009. Rexdale, Ontario: United Food and Commercial Workers.

Walia, H., 2009. The Kenney doctrine: temporary workers trump refugees in Canada Rabble [online]. Available from: http://rabble.ca/news/2009/12/kenney-doctrinetemporary-workers-trump-refugees-canadas-immigration-regime [Accessed December 9 2009]. 